\title{
Long-term results of catheter ablation for atrial fibrillation in 866 patients
}

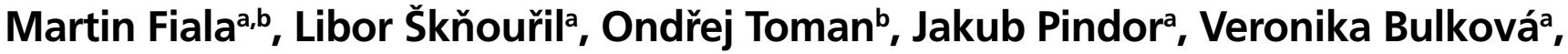 \\ Jan Chovančíka, Radek Neuwirtha , Rưžena Lábrováb, Jaroslav Januškaa , \\ Jindřich Špinarb
}

a Oddělení kardiologie, Kardiocentrum, Nemocnice Podlesí, a. s., Třinec, Česká republika

b Interní kardiologická klinika, Lékařská fakulta Masarykovy univerzity a Fakultní nemocnice Brno, Brno, Česká republika

\section{INFORMACE O ČLÁNKU}

Historie článku:

Došel do redakce: 23. 9.2012

Přepracován: 30. 10. 2012

Príijat: 31. 10. 2012

Dostupný online: 9. 11. 2012

\section{Keywords:}

Atrial fibrillation

Catheter ablation

Outcome

Recurrent arrhythmias

\begin{abstract}
Purpose: This study presents eight-year experience with ablation techniques, recurrent arrhythmias, and long-term outcomes in patients undergoing catheter ablation for atrial fibrillation (AF).

Methods: Catheter ablation of AF was performed in 866 consecutive patients in a total of 1,272 ablation procedures. Ablation strategy and procedure endpoints were left at the operator's discretion. Total study population and groups of paroxysmal $(n=508 / 59 \%)$, persistent $(n=102 / 12 \%)$, and long-standing persistent AF $(n=256 / 29 \%)$ were evaluated.

Results: Pulmonary vein isolation alone or with cavo-tricuspid isthmus ablation was accomplished in $36 \%$ of the patients. It was significantly more often used in paroxysmal AF than in persistent or long-standing persistent AF (both $p<0.001$ ). More extensive ablation prevailed in persistent AF types. Ablation was repeated in 307 (35\%) patients. Patients with long-standing persistent AF underwent significantly more repeat procedures than patients with paroxysmal AF $(p<0.001)$ or persistent $\operatorname{AF}(p=0.001)$. Recurrent AF dominated before the first repeat ablation in $68 \%$ cases, while recurrent atrial tachycardia (AT) prevailed before the second $(73 \%)$, and third $(93 \%)$ repeat ablation. Patients with long-standing persistent AF presented with recurrent AT in $50 \%$ of the cases already before the first repeat ablation. At the end of $49 \pm 26$ months follow-up, $83 \%$ of the patients remained in stable sinus rhythm (SR); $70 \%$ of the patients without antiarrhythmic drugs. SR maintenance was insignificantly superior in long-standing persistent AF group $(91 \%)$ compared to paroxysmal AF (82\%) and persistent AF patients (68\%).

Conclusion: Patients with persistent AF types underwent more extensive initial ablation. Patients with long-standing persistent AF experienced best long-term outcome likely as a consequence of higher number of repeat ablation procedures.
\end{abstract}

SOUHRN

Cíl: Tato studie analyzovala osmileté zkušenosti s ablačními technikami, recidivujícími arytmiemi a dlouhodobými výsledky u pacientů, kteří podstoupili katetrovou ablaci pro fibrilaci síní (FS).

Metodika: Katetrovou ablaci FS podstoupilo 866 konsekutivních pacientů v celkovém počtu 1272 výkonů. Ablační strategie a cílové momenty výkonu byly individuální podle rozhodnutí operatéra. Hodnotily se výsledky v celém souboru a ve skupinách paroxysmální $(n=508 / 59 \%$, perzistentní $(n=102 / 12 \%)$ a dlouhodobé perzistentní FS ( $n=256 / 29 \%$ ).

Výsledky: Izolace plicních žil samotná nebo spojená s ablací kavotrikuspidálního můstku byla provedena u $36 \%$ pacientů. Častěji byla použita u pacientů s paroxysmální FS než u pacientů s perzistentní nebo dlouhodobou perzistentní FS (obě $p<0,001$ ). Naopak rozsáhlejší ablace převažovala u pacientů s perzis-

Adresa: Doc. MUDr. Martin Fiala, Ph.D., Oddělení kardiologie, Kardiocentrum, Nemocnice Podlesí, a. s., Konská 453, 73961 Trínec, e-mail: martin.fiala@gmail.com DOI: 10.1016/j.crvasa.2012.10.006

(C) 2012, ČKS. Published by Elsevier Urban and Partner Sp. z o.o. All rights reserved. 
Kličová slova:

Fibrilace síní

Katetrová ablace

Recidivující arytmie

Výsledky tentními formami FS. Ablace se opakovala u 307 (35 \%) pacientů. Pacienti s dlouhodobou perzistentní FS podstoupili opakovanou ablaci signifikantně častěji než pacienti s paroxysmální FS $(p<0,001)$ nebo perzistentní FS $(p=0,001)$. Recidivující FS dominovala před první opakovanou ablací v $68 \%$ prípadech, naopak recidivující síňová tachykardie (ST) převažovala před druhou (73\%) a třetí (93\%) opakovanou ablací. Pacienti s dlouhodobou perzistentní FS měli recidivu ST v $50 \%$ prípadů již před první opakovanou ablací. Na konci sledování $49 \pm 26$ měsíců mělo stabilní sinusový rytmus (SR) $83 \%$ pacientů; přičemž $70 \%$ pacientů bez léčby antiarytmiky. Udržování SR bylo nesignifikantně lepší u pacientů s dlouhodobou perzistentní FS (91\%) než u pacientů s paroxysmální FS ( $82 \%$ ) nebo perzistentní FS (68 \%).

Závěr: U pacientů s perzistentními formami FS se prováděla rozsáhlejší iniciální ablace. Pacienti s dlouhodobou perzistentní FS zaznamenali nejlepší dlouhodobé výsledky nejspiše v důsledku častějších opakovaných ablací.

\section{Introduction}

Catheter ablation can effectively cure atrial fibrillation $(\mathrm{AF})$, yet, early as well as late arrhythmia recurrences occur and multiple procedures of different extent may be required to eventually restore stable sinus rhythm (SR) [1-4]. Although in theory absolutely effective, AF ablation in routine clinical practice still remains limited to a selected population of patients with variable centerand operator-related outcomes [5].

This retrospective study analyzed ablation techniques, recurrent arrhythmias, and long-term ablation outcomes in consecutive patients who underwent ablation procedure for $\mathrm{AF}$ within a period of eight years.

\section{Methods}

\section{Patient population}

The study included 866 consecutive patients who underwent catheter ablation for symptomatic AF between June 2003 and June 2011. These patients underwent a total of 1,272 ablation procedures for AF or residual atrial tachycardia (AT). Repeat procedures were accomplished by the end of September 2011. First ablation was performed in the main study center, while for later working restraints in this center some of the repeat ablations had to be performed in the second study center. Follow-up was closed on December $31^{\text {st }}, 2011$, so that the minimum follow-up period amounted to 6 months since the first ablation, and 3 months since the last ablation, respectively. The study population was distributed into three groups of patients with paroxysmal $(n=508 / 59 \%)$, persistent $(n=102 / 12 \%)$, and long-standing persistent AF $(n=256 / 29 \%)$. Baseline characteristics are summarized in Table 1.

\section{Ablation procedure and pre-ablation and post-ablation management}

The details about ablation techniques and preablation and postablation management were described previously [6-9]. Briefly, warfarin was discontinued and replaced by low-molecular-weight heparin for 5 days prior to ablation. Laboratory tests and transthoracic/transesophageal echocardiography were performed $<48$ hours prior to the ablation procedure to exclude thrombus and to obtain other parameters. Antiarrhythmic drugs (AADs) were often continued throughout the procedure in the early stages of our ablation practice, while there was tendency to discontinue AADs before ablation in the later years.

For the ablation procedure, a 10-pole catheter (Daig, St. Jude, Minnetonka, MN, USA) was positioned in the coronary sinus (CS), and a 10-pole ring catheter (Lasso, Biosense Webster, Diamond Bar, CA, USA) and a mapping/ablation catheter (ThermoCool or NaviStar ThermoCool, Biosense Webster) were inserted via two $8 \mathrm{~F}$ transseptal sheaths (Daig, St. Jude) in the left atrium (LA) and pulmonary veins (PVs). Heparin was given to maintain activated clotting time (ACT) between 250-350 seconds in the first years, and 300-400 seconds in the later years. Bipolar endocardial electrograms were filtered at a band-pass setting of $30-500 \mathrm{~Hz}$ and displayed at 200 $\mathrm{mm} / \mathrm{s}$ speed (Cardiolab System, Prucka Engineering, Sugar Land, TX, USA). A few early ablation procedures were performed conventionally without using 3-dimensional non-fluoroscopic mapping, while a majority of ablation procedures were guided by 3-dimensional electroanatomical left atrial (LA) and possibly right atrial (RA) mapping (CARTO system, Biosense Webster). Radiofrequency energy was applied with a Stockert generator (Biosense Webster). The power and temperature limits evolved over time to finally use irrigation of $17-30 \mathrm{ml} / \mathrm{min}$ (heparinized $0.9 \%$ saline) and temperature and power limits of $42{ }^{\circ} \mathrm{C}$

\begin{tabular}{|c|c|c|c|c|c|c|c|}
\hline & $\begin{array}{c}\text { Total } \\
(n=866)\end{array}$ & $\begin{array}{l}\text { Paroxysmal } \\
\text { AF }(n=508)\end{array}$ & $\begin{array}{c}\text { Persistent } \\
\text { AF }(n=102)\end{array}$ & $\begin{array}{l}\text { LS persistent } \\
\text { AF }(n=256)\end{array}$ & $\begin{array}{c}p \\
\text { Parox-Pers }\end{array}$ & $\begin{array}{c}p \\
\text { Parox-LS Pers }\end{array}$ & $\begin{array}{c}p \\
\text { Pers-LS Pers }\end{array}$ \\
\hline Females & $238(27 \%)$ & $153(30 \%)$ & $27(26 \%)$ & $58(23 \%)$ & 0.583 & 0.097 & 0.550 \\
\hline Age (years) & $57 \pm 10(21-82)$ & $56 \pm 10(21-82)$ & $61 \pm 9(32-78)$ & $58 \pm 9(24-79)$ & $<0.001$ & 0.056 & 0.009 \\
\hline $\mathrm{CHADS}_{2}$ score & $1.2 \pm 1.0(0-5)$ & $1.1 \pm 1.0(0-5)$ & $1.3 \pm 0.8(0-4)$ & $1.3 \pm 0.9$ & 0.028 & $<0.001$ & 0.792 \\
\hline LA diameter (mm) & $44 \pm 6(25-76)$ & $42 \pm 5(25-61)$ & $46 \pm 7(29-76)$ & $48 \pm 5(33-68)$ & $<0.001$ & $<0.001$ & 0.003 \\
\hline LVEF (\%) & $57 \pm 7(20-72)$ & $59 \pm 5(35-72)$ & $56 \pm 8(25-65)$ & $54 \pm 9(20-67)$ & $<0.001$ & $<0.001$ & 0.028 \\
\hline
\end{tabular}

AF - atrial fibrillation; LA - left atrial; LS - long-standing; LVEF - left ventricular ejection fraction; Parox - paroxysmal; Pers - persistent. 
and $35 \mathrm{~W}$ (limited to $20 \mathrm{ml} / \mathrm{min}$ and $20-25 \mathrm{~W}$ inside the CS) in the last 5 years.

The extent of ablation strategy and procedure endpoints differed among the patients; however, full PV isolation validated by the ring catheter was the mandatory procedure endpoint in all patients. Patients with long-standing persistent AF invariably received extensive ablation consisting minimally of the mandatory wide-area PV isolation and LA roof and mitral isthmus linear lesions; AF termination and SR restoration by radiofrequency applications were always pursued as an ideal procedure endpoint. Converted AT, macroreentry or localized, was characterized according to standard criteria and identified by the means of activation and entrainment mapping [10].

Heparin was stopped at the end of the procedure, and low-molecular-weight heparin was administered until warfarin reached full therapeutic effect. Warfarin was stopped following a minimum of 6 weeks after uncomplicated PV isolation for paroxysmal AF up to 6 months after complex ablation for persistent $A F$ in case of stable SR, preserved LA appendage outflow velocity (generally $\geq 40 \mathrm{~cm} / \mathrm{s}$ ), and no other conditions favoring permanent anticoagulation. In the later years, there was a tendency to avoid re-initiation of AADs; however, they were sometimes resumed to stabilize SR in the early post-ablation course.

\section{Follow-up}

Patients were seen at the outpatient department after 6 weeks, 3, 6, 9, and 12 months, and then every 6 months in the first post-ablation years. Patients with stable SR long-term were later periodically contacted over phone. ECG documentation consisted of 12-lead ECG recordings at every visit and interim visits at local cardiologists and 24-hour ECG recordings several times a year. In multiple patients, a 2-3-week trans-telephonic ECG monitoring with loop-recorder every six months was employed, while many others received an episodic recorder for daily many ECG recordings, both random and during symptoms for up to one-year period. Arrhythmia recurrence included ECG documented AF/AT, and also any history of palpitations suggestive of AF/AT lasting $>30$ seconds.

\section{Data presentation}

The outcomes are presented in total and separately for the three standard AF types (paroxysmal, persistent, and long-standing persistent) according to the current consensus for AF treatment [11]. Variability in the arrhythmogenic substrates with wide overlap among the AF types individualized ablation strategy. Further, ablation strategy varied depending on the operator's discretion, individual skill/learning curve, and/or preset protocols of studies, in which some of the patients were included. Finally, radiofrequency energy settings and follow-up density varied due to natural evolution of the method and means of ECG monitoring available. Therefore, for the purpose of this retrospective analysis, categorization of the presented data had to be simplified.

Ablation extent was distributed into 5 categories: 1) $P V$ isolation (PV encircling with isolation only); 2) PV isolation + cavotricuspid isthmus (CTI) ablation; 3) LA ablation (PV isolation + possible CTI ablation + different extent of additional LA ablation outside PVs in terms of linear and/or electrogram-guided ablation; 4) LA ablation + CS ablation (CS ablation might include limited distal CS ablation to finalize mitral isthmus conduction block, or full CS isolation that eliminated localized AF sources within the CS, or was performed during AF ongoing after extensive LA ablation); and 5) LA ablation (+ CS ablation) + RA ablation (RA ablation might include inter-caval line and/or electrogram-guided ablation).

Recurrent arrhythmias were classified into: 1) paroxysmal AF; 2) persistent AF; 3) paroxysmal AT; and 4) persistent AT. If the patient presented with recurrent AT, a single AT type versus $\geq 2$ AT types were differentiated by the means of invasive mapping. AT decelerated by prior radiofrequency energy application, or macroreentry AT rotating alternately in both directions was still considered one distinct AT type.

Final ablation outcome was shown as: 1) SR maintenance with/without AADs; 2) SR maintenance without AADs; 3) recurrences of paroxysmal AF/AT; and 4) recurrence of persistent AF/AT.

\section{Statistical analysis}

Continuous variables were expressed as mean \pm standard deviation and compared by the 2-tailed Student's t-test for independent samples. Categorical variables were expressed as percentages and compared by $x^{2}$-test. Arrhythmia-free survival in the respective groups was compared by Kaplan-Meier survival analysis with log-rank test. A $p$ value $<0.05$ was considered significant. STATISTICA vers.6.1 (Statsoft, Inc.) was used for the analysis.

\section{Results}

\section{Initial ablation extent}

PV isolation alone or with CTI ablation was accomplished in $36 \%$ of the patients. It was significantly more often performed in patients with paroxysmal AF than in patients with persistent or long-standing persistent AF (both $p<0.001)$. More extensive LA ablation was employed in another $38 \%$ of the patients; significantly more often in patients with persistent AF compared to paroxysmal $\operatorname{AF}(p<0.001)$ or long-standing persistent AF $(p=0.002)$, while there was no difference between the latter two groups $(p=0,464)$. LA ablation + CS ablation, or LA (+ CS ablation) + RA ablation were performed in another $16 \%$ and $9 \%$ patients, respectively. LA ablation + CS ablation was more frequently performed in both persistent $A F$ groups than in paroxysmal AF patients (both $p<0.001$ ); there was no difference between persistent and long-standing persistent AF groups $(p=0.168)$. Finally, LA ablation (+ CS ablation) + RA ablation was significantly more often carried out in patients with long-standing persistent AF compared to paroxysmal or persistent AF patients (both $p<0.001$ ) (Fig. 1).

\section{Repeat ablation}

The 866 patients underwent a total of 1,272 ablation procedures (1.5 procedure/patient). A single ablation was performed in 559 (65\%) patients, while ablation was re- 


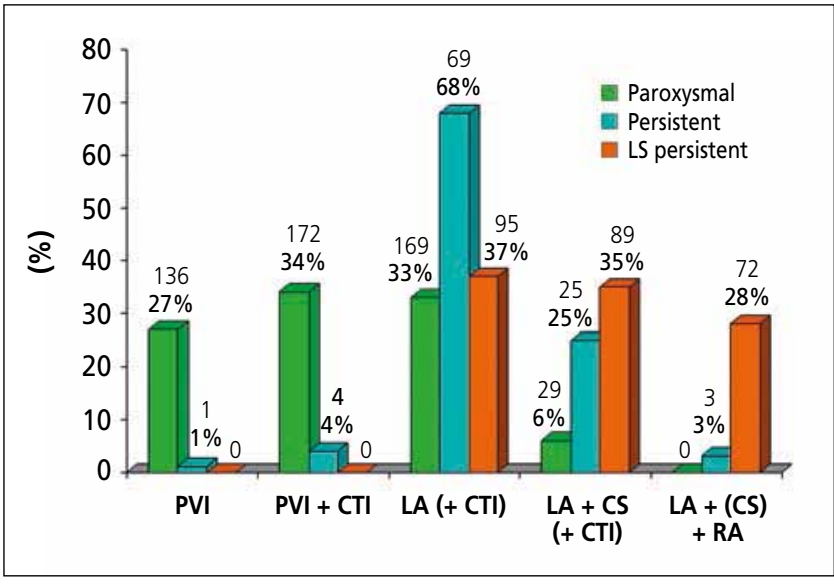

Fig. 1 - Ablation strategy employed in different AF groups at the initial ablation. Simple PV isolation dominated in paroxysmal AF, more extensive ablation including left atrium outside pulmonary veins, coronary sinus, and right atrium prevailed in persistent $A F$ types. See details in the text.

CS - coronary sinus ablation; CTI - cavo-tricuspid isthmus ablation; LA - left atrial extra-pulmonary vein ablation; LS - long-standing; $\mathrm{PVI}$ - pulmonary vein isolation; RA - right atrial ablation.

peated in 307 (35\%) patients. Two and three repeat ablation procedures were performed in $71(8 \%)$ and $14(2 \%)$ patients, respectively. Patients with long-standing persistent AF underwent two ablation procedures more often than patients with paroxysmal AF $(p<0.001)$ or persistent $\operatorname{AF}(p=0.001)$. Similarly, they more frequently underwent three ablation procedures $(p<0.001$ for comparison with

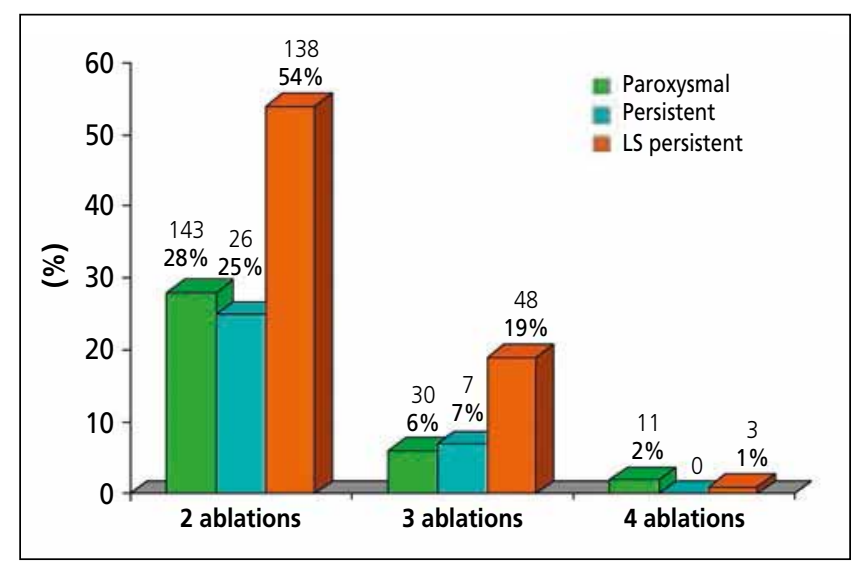

Fig. 2 - Repeat ablation procedures in different AF groups. Patients with long-standing (LS) persistent AF underwent significantly more repeat (first repeat and second repeat) ablation procedures. paroxysmal AF group, and $p=0.013$ for comparison with persistent AF group). There we no significant differences between paroxysmal and persistent AF patients in the counts of two $(p=0.678)$ or three $(p=0.728)$ ablation procedures (Fig. 2).

\section{Ablation procedure characteristics}

Procedure, fluoroscopy, and radiofrequency delivery times of all 1,272 ablation procedures were $272 \pm 81$ (60-600), $29 \pm 16(5-105)$, and $92 \pm 41$ (5-242) minutes, respectively. Respective times in different AF groups are compared in Table 2. Procedure time in paroxysmal AF group was significantly shorter than the time in persistent AF groups. On the contrary, fluoroscopy time in the long-standing persistent AF group was significantly shorter than in the other groups.

\section{Recurrent arrhythmias}

The spectrum of recurrent arrhythmias evolved with the number of repeat ablation procedures, and also depended on the AT type/extent of ablation strategy. AF dominated before the first repeat ablation in $68 \%$ of the cases (paroxysmal AF - 41\%, persistent/long-standing persistent AF-27\%), while AT prevailed before the second $(73 \%)$, and third $(93 \%)$ repeat ablation (Fig. 3). There was a clear tendency to more frequent AT recurrence already before the first repeat ablation in long-standing persistent AF group (50\%) or persistent AF group (35\%) when compared with paroxysmal AF group $(14 \%)$ ( $p<0.001$ for comparison between long-standing and paroxysmal AF; $p=0.041$ for comparison between persistent and paroxysmal AF; $p=0.372$ for comparison between persistent and long-standing persistent $A F$ ) (Figure 4).

Persistent AF/AT prevailed after ablation of primary persistent (in $77 \%$ of the cases; $p=0.002$ ) or long-standing persistent AF (in $83 \%$ of the cases; $p<0.001$ ) compared with paroxysmal AF group, in which persistent AF/AT recurred after the initial ablation in only $27 \%$ of the cases (Fig. 4).

A single AT versus $\geq 2$ ATs were present before repeat ablation in 65 versus 108 cases, respectively. Presence of $\geq 2$ ATs dominated over single AT in all three ablation groups (35 versus 12 in paroxysmal AF group, 10 versus 3 in persistent AF group, and 63 versus 50 in long-standing persistent AF group).

\section{Long-term outcome}

Ten ( $1 \%$ ) patients (mean age $61 \pm 12$, range 34-78 years) died $31 \pm 19(5-60)$ months after the last ablation. These patients belonged to the groups of paroxysmal $(0.8 \%)$,

\begin{tabular}{|c|c|c|c|c|c|c|}
\hline & $\begin{array}{l}\text { Paroxysmal } \\
\text { AF }(n=692)\end{array}$ & $\begin{array}{l}\text { Persistent } \\
\text { AF }(n=135)\end{array}$ & $\begin{array}{l}\text { LS persistent AF } \\
\quad(n=445)\end{array}$ & $\begin{array}{c}P \\
\text { Par-Pers }\end{array}$ & $\begin{array}{c}P \\
\text { Par-LS Pers }\end{array}$ & $\begin{array}{c}P \\
\text { Pers-LS Pers }\end{array}$ \\
\hline Procedure time (min) & $263 \pm 82$ & $290 \pm 82$ & $282 \pm 79$ & $<0.001$ & $<0.001$ & 0.264 \\
\hline Fluoroscopy time (min) & $32 \pm 19$ & $31 \pm 17$ & $23 \pm \times 10$ & 0.531 & $<0.001$ & $<0.001$ \\
\hline RF delivery time (min) & $89 \pm 37$ & $94 \pm 38$ & $96 \pm 47$ & 0.174 & 0.014 & 0.761 \\
\hline
\end{tabular}

AF - atrial fibrillation; LS - long-standing; Par - paroxysmal; Pers - Persistent; RF - radiofrequency energy. 


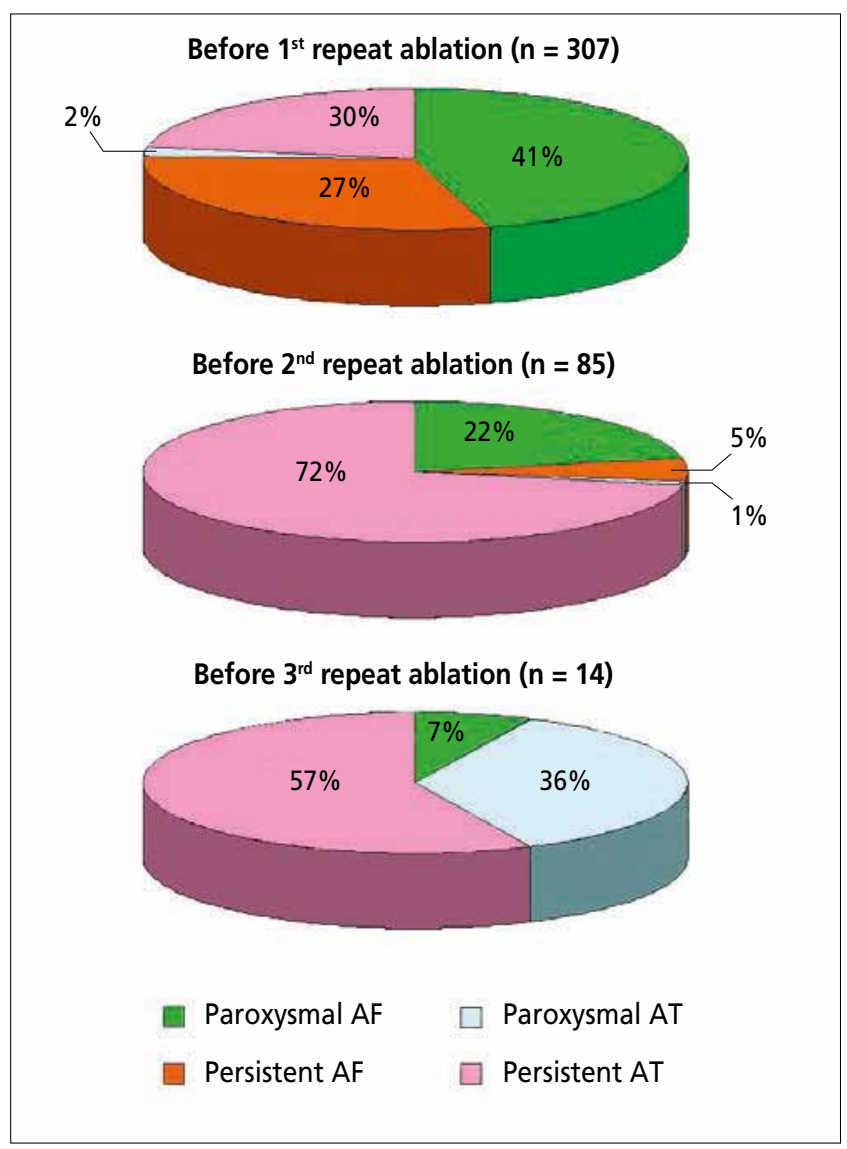

Fig. 3 - Proportions of different types of recurrent arrhythmia in all patients undergoing repeat ablation procedures. Atrial fibrillation (AF) prevailed before the first repeat ablation, atrial tachycardia (AT) represented dominant recurrent arrhythmia before the second and third repeat ablation.

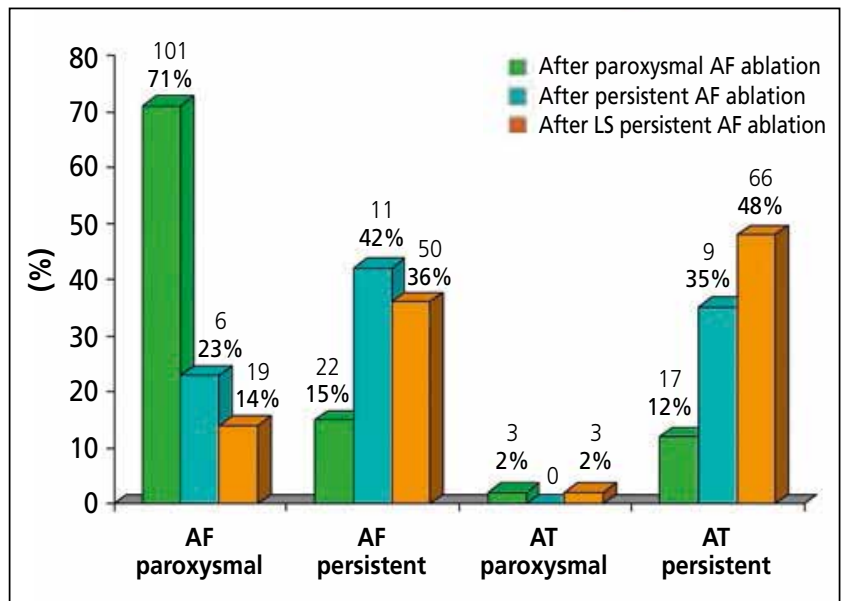

Fig. 4 - Proportions of recurrent arrhythmias before the first repeat ablation in the groups of different primary AF types. Recurrent paroxysmal AF dominated after ablation of paroxysmal AF, recurrent persistent AT prevailed after ablation of long-standing persistent AF. More frequent recurrent persistent AF after ablation of persistent AF as compared to dominating AT after long-standing persistent AF ablation may reflect more extensive initial ablation strategy in the latter group. persistent $(0.9 \%)$, and long-standing persistent AF (2\%). The cause of death was cancer in 4 patients, cerebral hemorrhage while taking warfarin with international normalized ratio within the range $2-3$ in 2 patients, aortic dissection in 1 patient, infective endocarditis as a resistant complication of later pacemaker implantation in 1 patient, heart failure due to recurrent myocardial infarction in 1 patient, and motorcycle accident in 1 young patient. In addition, $1(0.1 \%)$ patient with paroxysmal AF died in the year 2005 of fulminant cardiac tamponade that developed 26 hours after the first ablation procedure.

Kaplan-Meier curves of arrhythmia-free survival after the initial and final ablation are shown in Fig. 5. There was a significantly better AF/AT-free survival in paroxysmal than in persistent or long-standing persistent AF patients after the initial ablation (Panel A). This disparity was leveled off after the final ablation between the paroxysmal and long-standing persistent AF groups, while the outcome remained significantly worse in the persistent AF group (Panel B).

At the end of $49 \pm 26(6-102)$ month total follow-up time, and $41 \pm 26$ (3-102) month follow-up period since the last ablation, $717(83 \%)$ patients were in stable SR; $605(70 \%)$ patients did not use class I or III AAD. Paroxysmal or persistent AF/AT recurrences continued in $101(12 \%)$ and $48(5 \%)$ patients, respectively. SR maintenance was insignificantly superior in long-standing persistent AF patients (233 [91\%] patients) compared to paroxysmal AF patients (415 [82\%] patients) $(p=0.335)$. On the contrary, the worst outcome was observed in the group of persistent AF (69 [68\%] patients in SR) ( $p=0.264$ for comparison with paroxysmal AF, $p=0.099$ for comparison with long-standing persistent AF) (Fig. 6).

Warfarin use in $810(94 \%)$ patients before ablation was reduced to $269(31 \%)$ patients at the end of the follow-up period. Warfarin reduction was significant in paroxysmal AF group ( $89 \%$ versus $27 \%$ patients; $p<0.001$ ), persistent $\mathrm{AF}$ group ( $100 \%$ versus $48 \%$ patients, $p=0.001)$, and long-standing-persistent AF group (100\% versus $32 \%$ patients, $p<0.001$ ).

\section{Complications}

Twenty-two patients $(2.5 \%)$ experienced a major complication or complication potentially imperiling with long-term consequence. Cardiac tamponade requiring intervention occurred in $5(0.6 \%)$ patients, embolic stroke with complete recovery in $4(0.5 \%)$ patients, and transient ischemic attack in $5(0.6 \%)$ patients. Further complications included hemothorax from arterial or venous bleeding requiring surgical intervention in $2(0.2 \%)$ patients, suprarenal gland adenoma hemorrhage due to anticoagulation treated surgically in $1(0.1 \%)$ patient, protracted neuropraxis of the femoral nerve in $1(0.1 \%)$ patient, pulmonary edema in $1(0.1 \%)$ patient, sepsis due to atypical pneumonia in $1(0.1 \%)$ patient, and PV stenosis in $2(0.2 \%)$ patients. Groin vessel complications that were not listed were treated without sequel. We did not observe any atrio-esophageal fistula or phrenic nerve palsy. 
A

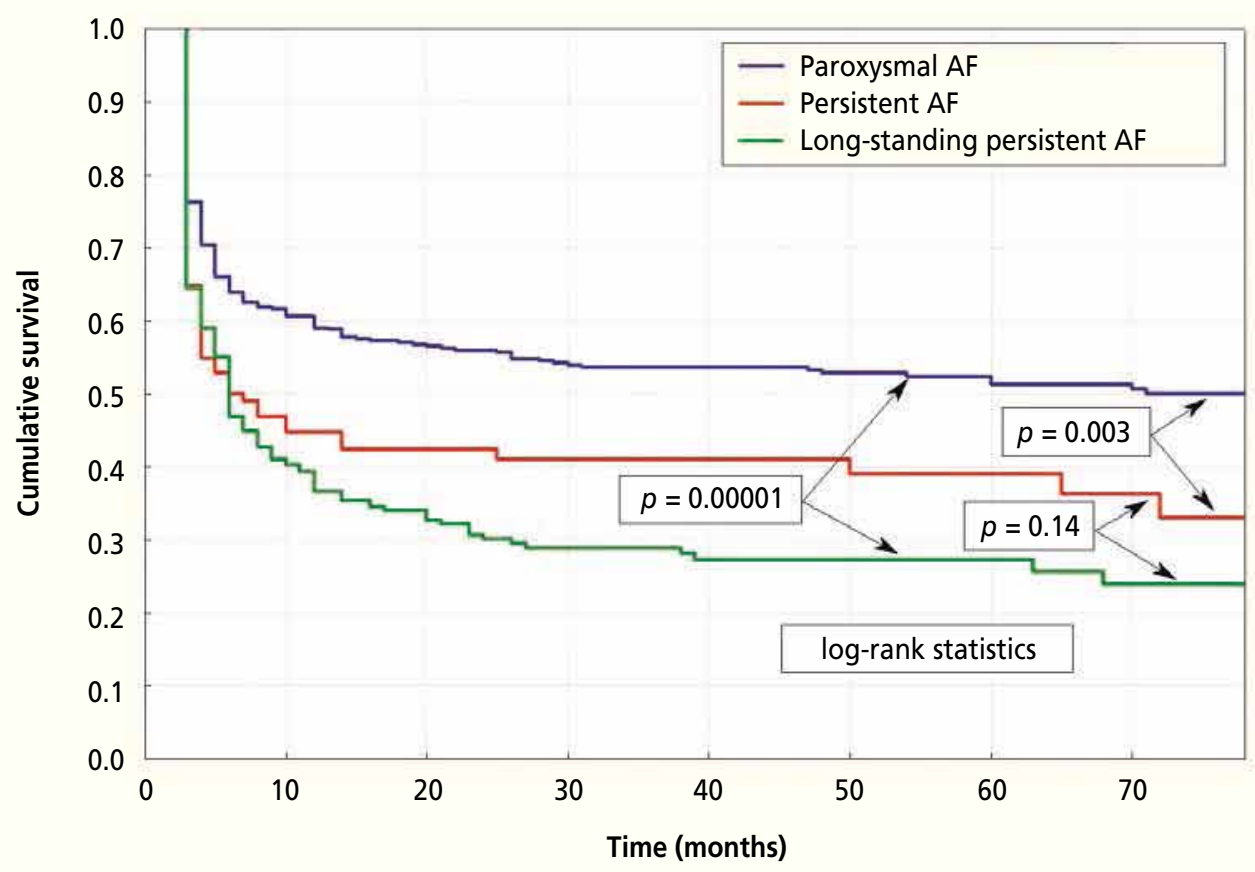

B

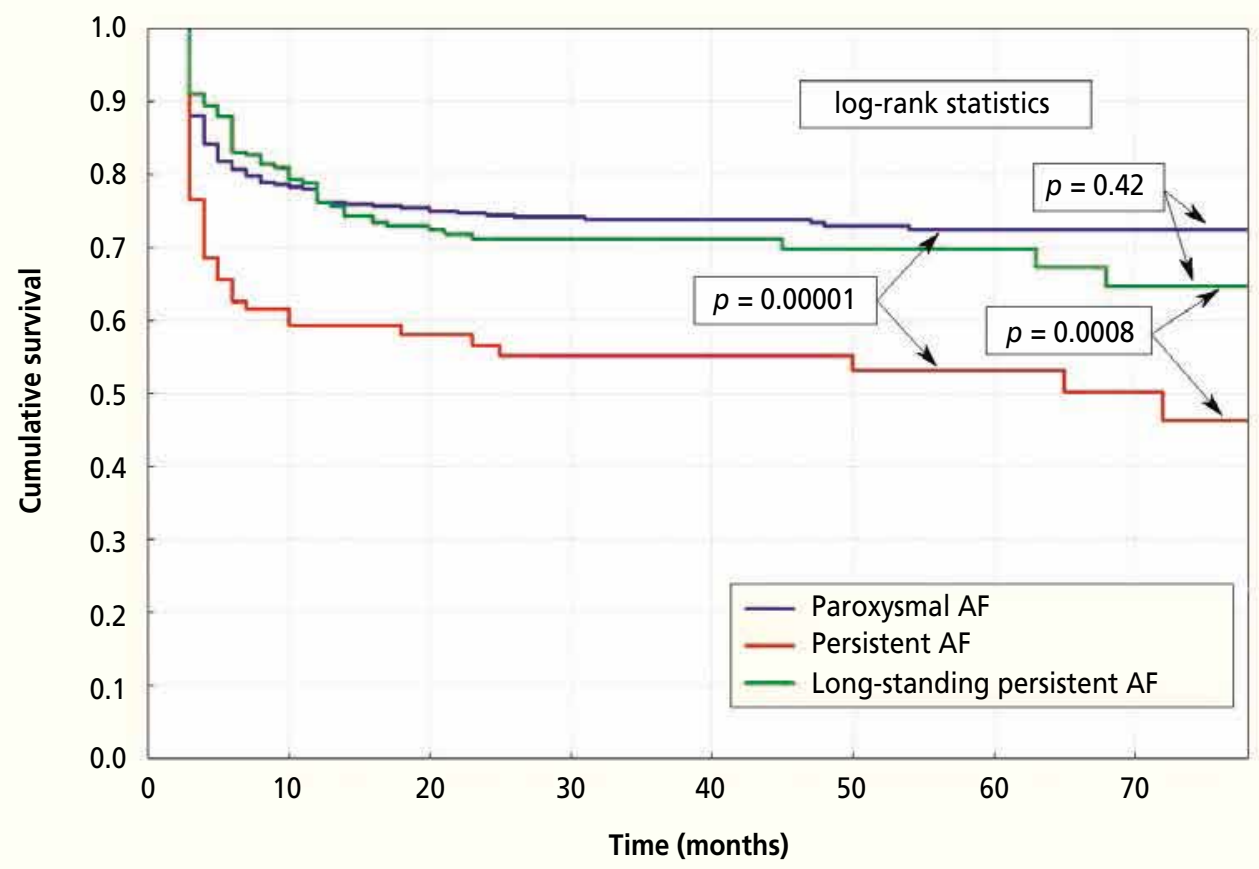

Fig. 5 - Kaplan-Meier curves of arrhythmia-free survival in the respective AF groups after the initial (A) and the last ablation procedure (B).

\section{Discussion}

This retrospective study analyzed long-term outcomes in a large number of consecutive patients undergoing catheter ablation for AF. The initial AF ablation was performed in one center, while for later working restraints in this center, some of the patients requiring timely repeat ablation had to be offered cure in another center. As these repeat ablation procedures were performed by one operator working in both centers, the study results roughly approximate eight-year single center experience. At the same time, the study results also reflected technological progress, evolution of ablation strategies, variability in the procedure endpoints, and learning curve of already experienced as well as beginning operators. The major findings are as follows: 1) at the initial ablation, simple PV isolation with possible CTI ablation was performed in $51 \%$ of the patients and was dominating ablation strategy in treatment of paroxysmal AF; 2) complex 


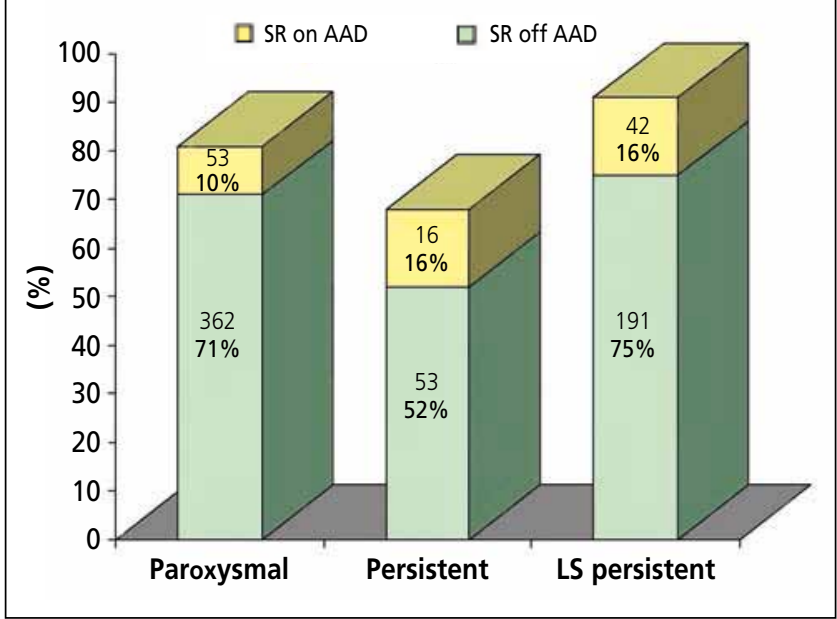

Fig. 6 - Sinus rhythm maintenance at the end of the follow-up. AAD - class I or III antiarrhythmic drug; SR - sinus rhythm.

ablation strategies at the initial procedure prevailed in persistent/long-standing persistent $A F$; 3) repeat ablation was most often performed in the group of long-standing persistent AF; 4) recurrent AT begun to prevail after the first repeat ablation, however, constituted half of the recurrent arrhythmias already after the initial extensive ablation for long-standing persistent AF; 5) best final long-term maintenance of SR was achieved in the long-standing persistent AF group.

\section{Ablation extent}

The extent of initial ablation strategy largely depended on the preset procedure endpoints. In general, extensive extra-PV ablation was more often required in persistent/long-standing persistent AF patients, in whom AF termination and $S R$ restoration by mere radiofrequency energy applications were pursued as the procedural endpoint of initial ablation. On the other hand, procedure endpoints markedly varied in paroxysmal AF patients. In some of these patients, simple PV isolation was considered a sufficient initial procedure endpoint [8]. In many others, in case of ongoing arrhythmia following PV isolation, efforts to restore SR by extra-PV LA/CS ablation were made. In addition, it was left at the operator's discretion, whether arrhythmia noninducibility was tested by incremental atrial pacing and/or pharmacological provocation with isoproterol and adenosine following PV isolation, and whether it was further pursued in case of AF/AT reinduction. Hence, even in some paroxysmal AF patients, localized AF/AT sources outside the PVs and/or residual macroreentry AT were further targeted.

\section{Recurrent arrhythmias and repeat ablation}

A noticeable disparity was observed between the recurrent arrhythmias after the initial ablation of paroxysmal, persistent, or long-standing persistent AF, respectively. Long-standing persistent AF patients presented with recurrent AT in half of the cases already after the initial ablation, clearly as a consequence of extensive ablation rendering the atria incapable of further disorganized fibrillatory activity. Although these ATs were often labeled as an unwanted proarrhythmic effect $[12,13]$, they frequently represent rather unmasked residual arrhythmia easier to re-ablate than recurrent AF [14]. Many of these ATs originated from a localized source likely existing prior to any ablation as a "background" AF driver that was unmasked and could be mapped selectively only after the initial extensive ablation [15]. Repeat ablation increased the proportion of recurrent ATs also in the paroxysmal AF group, so that the AT dominated before the second or third repeat ablation in all the groups.

Typically, following ablation of persistent/long-standing persistent AF, again persistent AF/AT recurred, while paroxysmal arrhythmia (mainly AF) dominated after ablation of paroxysmal AF. It may have important clinical implications for identification of recurrent arrhythmias. It appears that a majority of persistent AF/AT after ablation of persistent AF types can be revealed by means of standard follow-up with low risk of missing asymptomatic AF/AT episodes. Correlation of standard follow-up with longer-term ECG monitoring after ablation of long-standing persistent AF proved (unlike paroxysmal AF) very low incidence of clinically unrecognized AF/AT recurrences (data not shown).

AF substrate and sources are generally more complex in persistent $A F$ and usually progress with the duration of persistent AF phase. Consequently, initial ablation strategy is commonly extensive, and the need for repeat ablation procedures is larger [16-18]. However, there are several facts that might overestimate the contrast in the number of repeat ablation procedures between patients with long-standing persistent $A F$ and other AF types. First, patients with long-standing persistent AF were mostly ablated in prospective studies. To achieve ideal outcomes, they were frequently offered a repeat ablation even after several isolated AT episodes that might have been suppressible by AADs. On the other hand, in many paroxysmal AF patients, reduction in the AF/AT burden was occasionally tolerated as good arrhythmia control, and repeat ablation was not urged. Second, 26 patients with paroxysmal AF (compared to none with long-standing persistent AF) previously underwent $A F$ ablation in another center that was not calculated in this analysis. Including these ablation procedures, the proportion of paroxysmal AF patients with repeat ablation would increase from $28 \%$ to $33 \%$. Further, in separate studies, we have observed improved outcomes of a single ablation for long-standing AF as our experience increased. To achieve similar outcomes, repeat ablation was required in only $43 \%$ out of the last 80 patients, while it was needed in more than $60 \%$ of the preceding 100 patients. Therefore, outcome of extensive ablation for persistent or long-standing persistent AF is likely to improve with experience, and the difference of single ablation outcomes between long-standing persistent and paroxysmal AF will be gradually reduced. Finally, the discrepancy between long-standing persistent and persistent AF patients (only $25 \%$ of whom underwent a repeat ablation) does not corroborate lower need for repeat ablation in the latter group. In fact, ablation of persistent AF was the least effective, and appropriate repeat ablation was not indicated for other reasons (see bellow). 


\section{Long-term outcome}

Best long-term outcome was achieved in patients with long-standing persistent AF. Although the potential of extensive/repeat ablation for favorable long-term rhythm control in persistent AF types is high [19], the outcome of this study is rather unexpected $[3,5,20,21]$. It is likely that the extent of initial ablation and greater number of repeat ablations can effectively abolish even very complex arrhythmogenic sources. On the other hand, PV isolation for paroxysmal AF is more susceptible to missing possible (and not infrequent) extra-PV sources, and if repeat ablation concentrates only on PVs again and does not seek alternative sources, ablation failure and multiple repeat ablations may be at stake. In this respect, only $1 \%$ of long-standing persistent AF patients, but $2 \%$ of paroxysmal AF patients underwent four ablation procedures.

Obvious discrepancy between worse arrhythmia-free survival and, on the contrary, slightly better final SR maintenance in the group of long-standing persistent $A F$ has a possible explanation. Following ablation of paroxysmal AF, recurrences of paroxysmal arrhythmia usually emerged from unaffected or recovered ectopic focus. First AF/AT recurrence largely heralded subsequent repeated recurrences (albeit possibly reduced in quantity and duration), while isolated AF/AT recurrences were very rare. On the other hand, after long-standing persistent AF ablation, isolated recurrences of persistent AT that never reoccurred after cardioversion and/or adjusted AAD medication were not infrequent.

There are; however, also several facts that may put the outcome of paroxysmal AF ablation into different light. First, accidental self-terminating AF/AT episodes in the paroxysmal AF group were tolerated in some patients as a clinical improvement. On the contrary, rare arrhythmia episodes after ablation of long-standing persistent $A F$ were often indicated to timely repeat ablation (see also above). Second, by the end of the follow-up period, repeat ablations had been accomplished in a majority of eligible patients with long-standing persistent AF, while repeat ablation was successfully performed in some of the patients with paroxysmal AF after the follow-up had been closed. Finally, practically all ablation procedures for long-standing persistent AF were performed by the most experienced operator (note significantly shorter fluoroscopy times in this group), while learning curve of the beginning operators might have projected onto the outcomes of paroxysmal AF ablation.

Contradictory results in the persistent AF group also deserve several comments. The persistent AF patients represented a specific group in some aspects. They were significantly older, underwent fewest repeat procedures, and exhibited the worst outcome. Interestingly, they also constituted the smallest group. It can be speculated that indication to catheter ablation of long-standing persistent AF was affected by the presumption that only younger patients would benefit. Many of these patients entered the category of long-standing persistent AF by exceeding the 12-month limit of persistent AF phase thanks to prior multiple pharmacological attempts to restore SR and the time spent on waiting list. On the other hand, older patients with persistent AF were frequently referred to catheter ablation at the stage of paroxysmal
AF, but due to advanced arrhythmogenic substrate shortly developed persistent AF while awaiting ablation. It is also possible that the proportion of patients with persistent AF was undervalued because AF already persistent at the time of ablation was still counted as paroxysmal AF in some patients. Because these patients, based on the primary reference, were often approached as patients with paroxysmal AF, the need to enhance procedure extent and endpoints beyond PV isolation could be underestimated, or operators less experienced in extensive ablation were assigned to perform the procedure. As a result, the outcome of persistent AF ablation was not optimal. Simultaneously, the finding of advanced arrhythmogenic substrate together with older age might discourage both physicians and patients from repeat ablation.

\section{Conclusion}

Catheter ablation restored stable SR, and reduced the use of antiarrhythmic drugs and anticoagulation in a majority of patients. Patients with persistent AF types underwent more extensive initial ablation. Patients with long-standing persistent AF experienced best long-term outcome likely as a consequence of higher number of repeat ablation procedures.

\section{References}

[1] N. Sawhney, R. Anousheh, W. Chen, et al., Five-year outcomes after segmental pulmonary vein isolation for paroxysmal atrial fibrillation, American Journal of Cardiology 104 (2009) 366-372.

[2] A. Arya, G. Hindricks, P. Sommer, et al., Long-term results and the predictors of outcome of catheter ablation of atrial fibrillation using steerable sheath catheter navigation after single procedure in 674 patients, Europace 12 (2010) 173-180.

[3] W.S. Tzou, F.E. Marchlinski, E.S. Zado, et al., Long-term outcome after successful catheter ablation of atrial fibrillation, Circulation, Arrhythmia and Electrophysiology 3 (2010) 237-242.

[4] R. Weerasooriya, P. Khairy, J. Litalien, et al., Catheter ablation for atrial fibrillation: are results maintained at 5 years of follow-up, Journal of the American College of Cardiology 57 (2011) 160-166.

[5] R. Cappato, H. Calkins, S.A. Chen, et al., Updated worldwide survey on the methods, efficacy, and safety of catheter ablation for human atrial fibrillation, Circulation, Arrhythmia and Electrophysiology 3 (2010) 32-38.

[6] M. Fiala, J. Chovančík, P. Heinc, et al., Treatment of symptomatic intermittent atrial fibrillation by catheter ablation in the left atrium: immediate and long-term results in 150 patients, Vnitřní lékařství 51 (2005) 971-983.

[7] M. Fiala, J. Chovančík, R. Nevřalová, et al., Pulmonary vein isolation using segmental versus electroanatomical circumferential ablation for paroxysmal atrial fibrillation: over 3-year results of a prospective randomized study, Journal of Interventional Cardiac Electrophysiology 22 (2008) 13-21.

[8] M. Fiala, J. Chovančík, R. Nevřalová, et al., Termination of long-lasting persistent versus short-lasting persistent and paroxysmal atrial fibrillation by ablation, Pacing and Clinical Electrophysiology 31 (2008) 985-997.

[9] M Fiala, J. Chovančík, D. Wojnarová, et al., Results of complex left atrial ablation of long-lasting persistent atrial fibrillation, Journal of Interventional Cardiac Electrophysiology: an International Journal of Arrhythmias and Pacing 23 (2008) 189-198.

[10] M. Hocini, I. Nault, M. Wright, et al., Disparate evolution of right and left atrial rate during ablation of long-lasting persistent atrial fibrillation, Journal of the American College of Cardiology 55 (2010) 1007-1016. 
[11] H. Calkins, K.H. Kuck, R. Cappato, et al., 2012 HRS/EHRA/ECAS expert consensus statement on catheter and surgical ablation of atrial fibrillation: recommendations for patient selection, procedural techniques, patient management and follow-up, definitions, endpoints, and research trial design, Heart Rhythm 9 (2012) 632-696.

[12] C. Pappone, F. Manguso, G. Vicedomini, et al., Prevention of iatrogenic atrial tachycardia after ablation of atrial fibrillation: a prospective randomized study comparing circumferential pulmonary vein ablation with a modified approach, Circulation 110 (2004) 3036-3042.

[13] N. Sawhney, R. Anousheh, W. Shen, et al., Circumferential pulmonary vein ablation with additional linear ablation results in an increased incidence of left atrial flutter compared with segmental pulmonary vein isolation as an initial approach to ablation of paroxysmal atrial fibrillation, Circulation, Arrhythmia and Electrophysiology 3 (2010) 243-248.

[14] T. Rostock, I. Drewitz, D. Steven, et al., Characterization, mapping, and catheter ablation of recurrent atrial tachycardia after stepwise ablation of long-lasting persistent atrial fibrillation, Circulation. Arrhythmia and Electrophysiology 3 (2010) 160-169.

[15] S.M. Narayan, D.E. Krummen, W.J. Rappel, Clinical mapping approach to diagnose rotors and focal impulses for human atrial fibrillation, Journal of Cardiovascular Electrophysiology 3 (2012) 447-454
[16] M. Haïsssaguerre, M. Hocini, P. Sanders, et al., Catheter ablation of long-lasting atrial fibrillation: clinical outcome and mechanisms of subsequent arrhythmias, Journal of Cardiovascular Electrophysiology 16 (2005) 1138-1147.

[17] T. Rostock, D. Steven, B.A. Hoffmann, et al., Chronic atrial fibrillation is a biatrial arrhythmia: data from catheter ablation of chronic atrial fibrillation aiming arrhythmia termination using a sequential ablation approach, Circulation, Arrhythmia and Electrophysiology 1 (2008) 344-353.

[18] M.D. O'Neill, M. Wright, S. Knecht, et al., Long-term follow-up of persistent atrial fibrillation ablation using termination as a procedural endpoint, European Heart Journal 30 (2009) 1105-1112.

[19] T. Rostock, T.V. Salukhe, S.D. Drewitz, et al., Long-term single- and multiple-procedure outcome and predictors of success after catheter ablation for persistent atrial fibrillation, Heart Rhythm 8 (2011) 1391-1397.

[20] A. Sorgente, P. Tung, J. Wylie, et al., Six year follow-up after catheter ablation of atrial fibrillation: a palliation more than a true cure, American Journal of Cardiology 109 (2012) $1179-1186$.

[21] T.F. Chao, H.M. Tsao, Y.J. Lin, et al., Clinical outcome of catheter ablation in patients with nonparoxysmal atrial fibrillation: results of 3-year follow-up. Circulation. Arrhythmia and Electrophysiology 5 (2012) 514-520. 